\title{
Finding Cina
}

\section{A New Paradigm for Early Bugis History}

\author{
Ian Caldwell* \\ University of Leeds \\ i.caldwell@leeds.ac.uk \\ Kathryn Wellen \\ KITLV/Royal Netherlands Institute of Southeast Asian and Caribbean Studies \\ wellen@kitv.nl
}

\begin{abstract}
A central problem of early South Sulawesi historiography is the discrepancy between the portrayal of the ancient Bugis kingdom of Cina in historical and in literary sources. In the first, Cina is invisible; in the second, it looms large. This article uses Bugis genealogies and physical geography to reconstruct the extent of Cina and the location of its palace sites. In so doing it offers a new understanding of Cina and its northern neighbour Luwuq as complementary parts of a realm controlled by a single corporate cognatic descent group. This new understanding requires us to reconsider the origins of later Bugis kingdoms such as Bone, Soppeng, and Wajoq. It challenges us to consider Luwuq not as the cradle of Bugis civilization, but as part of a single economic and political complex focused on the fertile rice growing lands south of Lake Tempe.
\end{abstract}

\section{Keywords}

South Sulawesi - Cina - La Galigo - state formation - corporate descent groups

* The authors would like to thank two anonymous reviewers and Campbell Macknight for their helpful comments on an earlier draft of this paper.

(C) IAN CALDWELL AND KATHRYN WELLEN, 2017 | DOI: 10.1163/22134379-17302004

This is an open access article distributed under the terms of the prevailing CC-BY-NC license at the time of publication. 


\section{Introduction}

This article is concerned with the history of the Bugis people of South Sulawesi from 1200 to $1600 \mathrm{CE}$. In particular, we are concerned with the history of the kingdom of Cina, which has almost vanished from the historical record. South Sulawesi is the modern province of the southwestern peninsula of the Indonesian island of Sulawesi, and the largest rice-producing area in the archipelago after Java. The Bugis are the dominant ethnic group in the central areas of the peninsula; historically, they have been divided into separate kingdoms, each with its own history and traditions. The term kingdom is used here to describe loosely centralized polities occupying specific territories which archaeologists have termed complex chiefdoms. We argue in this article that Cina represents an early stage in the development of complex political life among the Bugis, when kinship was of central importance to political life.

Our picture of the Bugis kingdoms comes largely from sources written during the seventeenth and eighteenth centuries, at which point the kingdoms had been developing for at least four centuries and had expanded approximately to their modern regency borders. Writing in an Indic-derived script, initially on palm leaf and later on paper, began around $1400 \mathrm{CE}$, and over the following centuries the Bugis produced a wealth of written works, including a variety of historical genres such as elite genealogies, chronicles, and diaries. ${ }^{1}$ Based on these indigenous sources, historians have produced numerous regional histories of South Sulawesi ${ }^{2}$ as well as edited versions of major Bugis and Makasar chronicles. ${ }^{3}$

The development of writing also served to preserve the culturally important oral poetic tradition La Galigo, a series of linked episodes in a grand cycle spanning seven generations. ${ }^{4}$ The cycle begins with the arrival of gods on

1 See Cense 1966; Noorduyn 1961,1965; Caldwell 1988; Caldwell and Wellen 2016.

2 Many of these were published in the journal Bingkisan in Makassar (Ujung Pandang) from 1967 to 1969 by the Jajasan Kubudajaan Sulawesi Selatan. See, in particular, articles on the history of Soppeng, Tanete, Sidenreng, Pangkajene-kepulauan, and Sanrabone by Daeng Pattunru Abdurrazak, and on Soppeng and Luwuq by Zainal Abidin. A full set of Bingkisan is held in Canberra in the Australian National University library and the National Library of Australia.

3 Noorduyn 1955; Abdurrazak 1964; Wolhoff and Abdurrahim 1969; Rahim and Boharima 1975 .

4 The La Galigo is not a single work, but a series of episodes in a once widespread oral tradition. Its narratives are structured around seven generations of a divine family, and often focus on the adventures of the cultural hero, Sawerigading, prince of Luwuq, who marries his cousin 
earth and ends with their return to the upper and lower worlds, and reflects a pre-Islamic cosmos. The political geography of the La Galigo is very different from that of the seventeenth-century chronicles that record events dating back to the fifteenth century and possibly a little earlier. Some scholars have argued that the La Galigo presents an earlier stage of the peninsula's political evolution (Abdurrazak 1968; Zainal Abidin 1974; Pelras 1996). However, it has always been difficult to reconcile La Galigo's image of early South Sulawesi with the picture that emerges from genealogies, chronicles, and archaeological sources.

The early sections of the La Galigo are set in two prestigious Bugis kingdoms: Luwuq and Cina. Until as recently as 20 years ago, the precise locations of these kingdoms were unknown. The Origin of Complex Society in South Sulawesi Project (OxIS), which ran between 1997 and 200o, established that pre-Islamic Luwuq was located not at the modern provincial capital of Palopo, but rather on the north coast of the Gulf of Bone, today an isolated and sparsely populated region. It also concluded that Luwuq's palace centre at Malangke was established by migrants from the agricultural heartland around the great lakes of the central peninsula. Luwuq has long been considered the earliest and most prestigious kingdom in South Sulawesi, as well as the cradle of Bugis civilization. In the fifteenth and sixteenth centuries it dominated much of the peninsula (L. Andaya 1981:20-1). After its precipitous decline in the early seventeenth century, Luwuq survived in a weakened form until the twentieth century; Cina, on the other hand, seems to have disappeared by the early seventeenth century. ${ }^{5}$ In this article we argue that Cina and Luwuq were ruled by branches of a cognatic corporate descent group sharing mutual political and economic interests. ${ }^{6}$ Through an examination of the historical records of other Bugis

Wé Cudaiq, princess of Cina. While Sawerigading travels to many lands, Luwuq and Cina are focal points in the early sections of the epic. Today the La Galigo exists in a written form composed in a literary language that few can understand. The absence of Arabic loanwords and the almost complete omission of references to Islam indicate that the language of the La Galigo was fully developed as an oral tradition before 1600 , after which Islam became the confessed religion of most Bugis.

5 Around 1620 the settlement at Malangke was abandoned and a rump polity was established at Palopo. This remained the centre of the new Islamic kingdom of Luwuq until Dutch colonization (Bulbeck and Caldwell 2000; Mahmud 2003).

6 A corporate kinship group is a group of related individuals concerned with the control and transmission of economic resources (Seymour-Smith 1986:55). Characteristics of such groups include a unique identity, rules for including and excluding individuals, and empirical evidence of membership. In the case of the Bugis elite that controlled the peninsula's 
kingdoms, we account for Cina's disappearance in the sixteenth century as a result of the rise of new agricultural polities on its periphery. In so doing we resolve some of the anomalies of early Bugis history and sketch an outline of an integrated, unitary history of early South Sulawesi.

\section{Methodology and Findings}

To better understand Cina's role in the history of South Sulawesi, we examined what we believe to be one of the oldest historical sources of the peninsula. These are a set of six closely related genealogies of elite families in the western or upper Cenrana valley, a region associated in oral tradition with the vanished kingdom of Cina. ${ }^{7}$ The genealogies would appear to have been constructed in the seventeenth century from earlier written sources. ${ }^{8}$ These genealogies have been labelled the Royal Genealogy of Cina (Caldwell 1988:81); here we refer to the six genealogies collectively as the Cenrana Valley Genealogies (hereafter CVG). The individual genealogies are sufficiently consistent with each other in terms of structure and content that they appear to reflect a single historical tradition. These genealogies were edited by Caldwell (1988) in a diplomatic edition incorporating variant information from the other five versions. Unless indicated otherwise, references in this article to the CVG are references to this edited text. We also looked at related genealogies found in the Leiden University library (NBG 99:41-46), the structures of which are consistent with the CVG and contain additional related individuals. Collectively, these various genealogies contain the names of almost 200 individuals and span 16 generations, from mythical ancestors to seventeenth-century rulers.

The central lines of the genealogies are based upon a king list of between 20 and 22 individuals who are traditionally believed to have been the rulers of Cina. ${ }^{9}$ The first three rulers on this list are mythical, comprising a heavenly

agricultural heartlands, these characteristics included descent from a common ancestor, the importance of ascriptive status, and written genealogies that documented the group's members.

7 These genealogies are found in MAK 124:144-5; MAK 187:53-4; MAK 223:140-2; NBG 99:23641; NBG 100:31-2; NBG 101:30-3. These genealogies display close structural and linguistic similarities and can be divided into two distinct groups (Caldwell 1988:84).

8 This can be surmised from the inclusion in the genealogies of La Tenritatta, Arung Palakka, who became the paramount ruler of South Sulawesi after the defeat of Gowa in 1669.

9 This list is found in several independent Bugis codices. Caldwell (1988:81-7) sets out some of the problems of establishing a definitive list. 
being who descended from the sky, the to manurung Simpurusia, and his children and grandchildren. This mythical family is the source of the status of Cina's ruling elite, a source which is also shared by the royal family of Luwuq (Caldwell 1988: Figure 2-3). Rulers four to seven are essentially undatable, as they precede the development of writing, around 1400, and are drawn from oral tradition (Caldwell and Wellen 2016:127). The third of these rulers, La Balaonyi, is said to have been 'the first to own the sword that forms part of the regalia of Pammana to the present day' (Caldwell 1988:82). The first convincingly historical individuals are the three brothers-La Pottoanging, La Pasangkadi, and La Padasajati - who ruled at Wawolonrong, Pammana, and Tetewatu in the western Cenrana valley around 1400. Subsequent generations are indisputably historical. Both the tradition of the rulers of Cina and the CVG end with La Sangaji Pammana, who, it is claimed, requested on his deathbed that the kingdom be renamed Pammana (Zainal Abidin 1983:219). On this basis, we identify these genealogies as a record of the ruling elite of Cina, even though the name Cina does not occur in them.

Our approach was stimulated by the works of Campbell Macknight and Barbara Andaya. A seminal article by Macknight (1983) on the geography as described in the Chronicle of Bone (Macknight and Mukhlis, unpublished) set out an analysis of the expansion of the kingdom of Bone by relating events in historical sources to the geography of the peninsula. The simple but productive methodology inspired later scholars to conduct multidisciplinary field studies on the early history of the peninsula. ${ }^{10}$ Our specific focus on families as a central feature of traditional Southeast Asian statecraft was inspired by B. Andaya's 1993 monograph on southeast Sumatra; in particular, her analysis of the role of families in regional politics encouraged us to examine the elite marriages recorded in genealogies from the upper or western Cenrana valley. We recorded when and where these marriages took place on a large-scale map of the peninsula over 12 generations. In order to provide a broader context for our findings, we conducted similar exercises using genealogies associated with the ruling families of Bone, Wajoq, and Soppeng, three major neighbouring kingdoms. To cross-check our findings, we drew up a separate data set recording only the marriages ascribed to the rulers of Cina and their children; we then did the same for the kingdoms of Bone, Wajoq, and Soppeng. The aim in both exercises was to create a cartographic representation of each kingdom's geopo-

$10 \quad$ See for example Kallupa et al. 1989; Caldwell 1995; Bougas 1998; Bulbeck 200o; Bulbeck and Caldwell 200o; Fadillah and Mahmud 2000; Fadillah and Sumantri 200o; Caldwell and Lillie 2004; Caldwell and Bougas 2004; Druce 2009. 


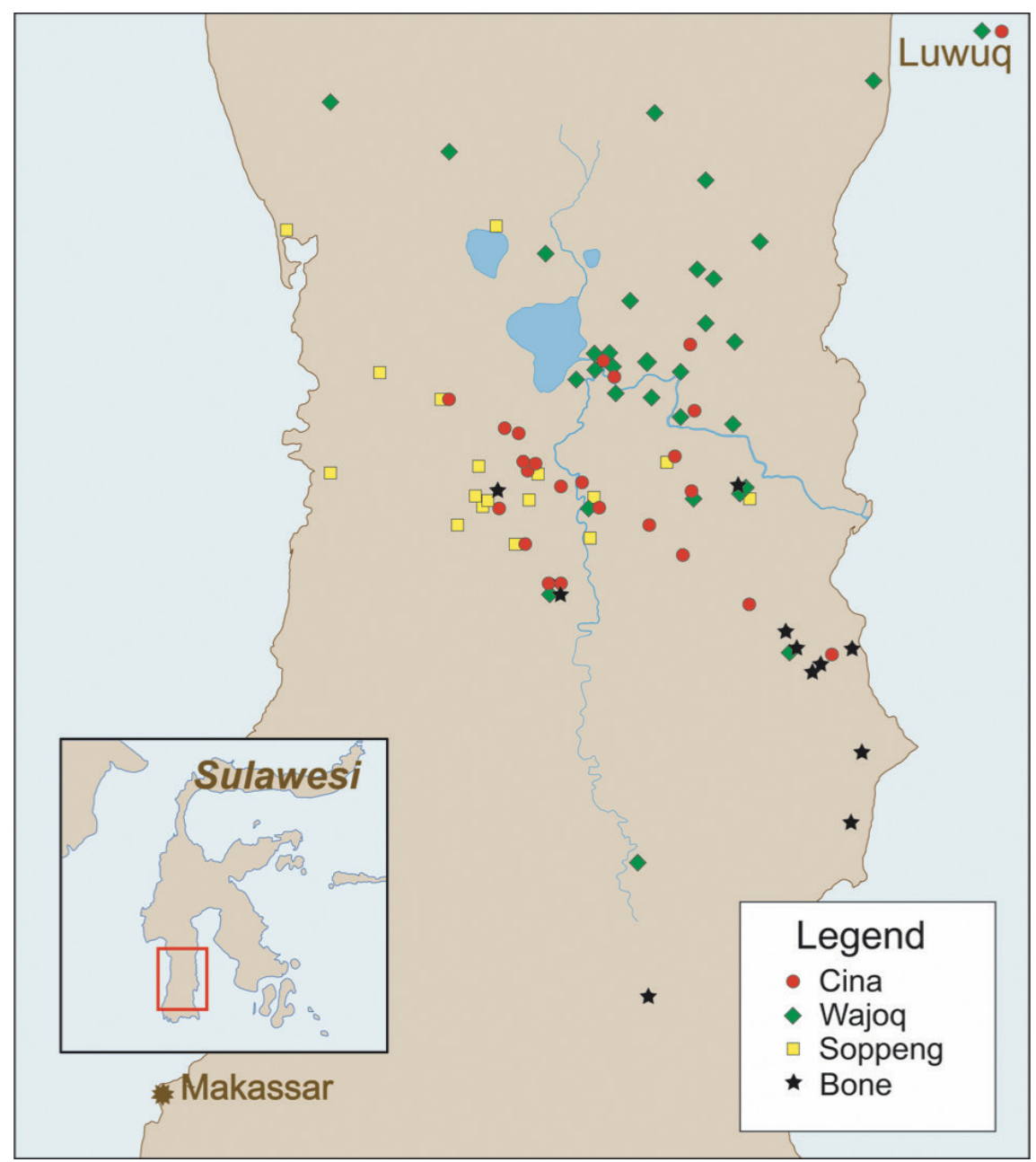

FIGURE $1 \quad$ Place names in the Cenrana valley genealogies

litical interests and its relationship to other kingdoms (Figure 1 ). ${ }^{11}$ We then interpreted these findings in the light of relevant textual and archaeological evidence.

By examining these elite marriages against the physical landscape, a surprising visual record of the political geography of the peninsula before c. 1600 began to emerge. Cina, which had previously been thought of as a small king-

11 A full list of toponyms can be found at http://www.oxis.org/resources-3/maps-ofsulawesi/ maps-caldwell-wellen-2017/index.html. 
dom to the east of its palace centre near Sengkang (Bulbeck and Caldwell 2000:83), showed a wider geographic distribution of elite marriages than any other Bugis kingdom. These marriages ranged from central Wajoq to Soppeng and southeastwards into Bone, including one at Taq, a stone's throw from Bone's palace centre at Watampone (Figure 1). The wide distribution of Cina's marriages in all probability reflects its geopolitical interests, and its ability to arrange these alliances suggests wide-ranging political influence. Three fifteenth-century marriages with members of Luwuq's ruling elite were recorded, as well as the marriage of Wé Tenrisida, a daughter of the early fifteenth-century ruler La Panyorongi, and a ruler of Sidenreng called Porié (NBG 99:241-2). These are among the very few inter-kingdom marriages before 1600 recorded in Bugis genealogies (Caldwell 1995:397). The pattern of marriages suggests that Cina had important economic interests to the southwest and southeast of its traditional palace centre, which has previously not been suspected. The marriage with Porié is particularly interesting because it shows that the central lakes were no barrier to Cina's marriage strategies. On the basis of this new understanding, Cina appears to have been a major power in the eastern and central parts of South Sulawesi during the fifteenth and sixteenth centuries. $^{12}$

Our combined cartographic exercises indicate that by the fifteenth century Cina had a presence not only in the Cenrana valley, but also in the Walanae valley and on lands south of the Cenrana valley. According to the CVG, Cina had a palace centre at Amali on the north Bone plain, founded by La Panyorongi, an early to mid-fifteenth century ruler. From here, Cina's rulers could command the rice-growing lands south of the Cenrana estuary, in what is now north Bone. The pattern of marriages of Cina's ruling family also reveals a deep interest in the rice lands of the Walanae valley. In the genealogies, La Panyorongi is recorded as also having founded Baringeng, which lies directly east of Soppeng's palace site. ${ }^{13}$ In subsequent generations three marriages were concluded by the rulers of Cina at Alliwengeng, Ganra, and Lompulle, which lie close to Baringeng. Two further marriages were concluded at Laumpulu ri Lau

12 Apart from the marriage with Porié, there is no evidence that Cina played a significant role west of Lake Sidenreng. The oral and written traditions of the Ajattappareng kingdoms make no reference to the La Galigo or to any member of the CVG. West of the central lakes, hill tribes appear to have played an important part in the establishment of lowland polities (Druce 2009).

13 Soppeng's palace site at the hill of Tinco, a couple of kilometres north of Watansoppeng, was surveyed in 1986 (Kallupa et al. 1989). When Caldwell visited the palace site at Baringeng in 1998 he found evidence of smelting in the form of iron slag. 
and Kebo, which lie less than $13 \mathrm{~km}$ from Baringeng. This evidence supports the idea that Cina was a major political power in the fourteenth, fifteenth, and sixteenth centuries. If this is so, why is Cina notably absent from the historical records?

One possible explanation for the paucity of references to Cina in the historical record is that the kingdom ceased to exist before the development of chronicles in the seventeenth and eighteenth centuries. ${ }^{14}$ However, this cannot explain the anomalous absence of folk literature on Cina. There are numerous oral traditions that revolve around the early rulers of Luwuq and some other Bugis kingdoms; ;5 as of yet, however, we have not found a comparable body of oral traditions for Cina. Therefore, we wondered whether we were looking not at an early kingdom but simply at an elite kinship group that extended from the upper Cenrana valley into what is now Wajoq, Soppeng, and Bone. To what extent did the genealogies stand for political alliances around the great lakes region from the fourteenth to the sixteenth century? There is no indication in the genealogies of a permanent locus of power: some Datu [ruler of] Cina appear to have ruled at Pammana, some at Baringeng and Amali, and others at Taq. On this slight evidence, Cina does not appear to have had a fixed centre; instead, its ruling elite appears to have taken advantage of an underpopulated, largely unopened landscape and the opportunities this offered for the development of agriculture. Might the idea of Cina therefore simply be a shorthand for an elite kinship group identified by descent from a single certain founding ancestor, the to manurung Simpurusia? ${ }^{16}$

The manuscripts contained in the CVG do not allow us to answer these questions in a conclusive manner. Instead, they present an ambiguous picture that could be interpreted in two ways. One is that the genealogies simply record a group of people claiming descent from the to manurung Simpurusia. The second is that the genealogies make a political statement about the reality of Cina, specifically an elite kinship group's right to rule over a geographical area. The latter interpretation is supported by the fact that genealogies record not just the names and marriages of individuals, but also where they married and where they ruled. While this is an unusual role for a genealogy, we have

\footnotetext{
14 Based on their internal structure, Macknight (2000) dates the chronicles of Gowa, Talloq, and Bone to no earlier than the late seventeenth century. Those of Wajoq and Tanete are from the eighteenth and nineteenth centuries.

15 See for example the stories of La Kilo, Kéqnikéqnié, To Apanangi, and To Anginraja in LATTM:112-30.

16 This is consistent with the contemporary Bugis practice of establishing one's relationship to others by enquiring about kinship and residence.
} 
argued elsewhere that Bugis genealogies are arranged around a central line of rulers (Caldwell and Wellen 2016) and that they might even be considered state genealogies. In the remainder of this article we compare the CVG against evidence from other Bugis historical sources, as well as the archaeological record.

\section{Cina in Mythological and Historical Literature}

While the epic oral poem La Galigo is not a historical source, the stories, as we have them in manuscript form from the eighteenth century and later, appear to preserve a very general memory of a time when Cina and Luwuq were the two major Bugis polities (Pelras 1996:50-1). The picture of Cina that emerges from the La Galigo is one of a trade-based polity centred around the mouth of the river where large boats could anchor, with a palace located nearby (Kern 1939). Some scholars have accepted this picture of a coastal, tradebased kingdom as historically valid (Zainal Abidin 1974; Pelras 1996) but the lack of archaeological evidence has led others to dismiss the La Galigo as a reliable historical source (Bulbeck and Caldwell 2000, 2008). The La Galigo may indeed contain information about early South Sulawesi, but it cannot simply be mined for facts because, as is typical of orally composed poetry, it uses anachronistic compression to construct its narrative. This means that it blends elements from different historical periods to form a composite picture. As Finlay (1964) argues for the Iliad, in the absence of supporting historical or archaeological documentation, it is impossible to separate these elements. In practical terms, when reading the La Galigo, it is difficult to place historically recognizable objects such as tampayan jars, muskets, gunpowder, and Malay cloths alongside the images of divine rulers and heaven-sent ships with golden masts and silken sails. However, the epic's depiction of Luwuq as a large, powerful, trade-based kingdom is broadly in accordance with the archaeological record (Bulbeck and Caldwell 200o). One might reason, therefore, that La Galigo's depiction of Cina has, like Luwuq, some basis in historical reality.

There are very few direct references to Cina in Bugis historical sources. Perhaps the best known is the reference in a chronicle of Wajoq to a prince of Cina who is attributed with the founding of Cinnotabbiq (Abdurrazak 1964:26). As we have stated, the name Cina does not occur in the CVG. If we accept that it records the elite of Cina and the settlements at which they ruled, the early core of the kingdom would appear to have been located in the upper part of the Cenrana valley. During the fifteenth century Cina appears to have expanded 
southwards into lands that are now in Bone and Soppeng. Extraordinary as it may seem, the existence of a kecamatan Cina in southern Bone suggests that at one time the whole of the Bone plain may have been under Cina's sway.

Cina's palace centre appears to have been located close to Sengkang in Wajoq, on the western edge of Lake Tempe. The main palace site is identified locally as the hill Allangkanangnge ri La Tanete ('the palace on the hilltop'; hereafter Allangkanangnge) at Sarapao, in Desa Wé Cudaiq. ${ }^{17}$ This low hill on the edge of a small valley yields a wealth of ceramic sherdage, reflecting continuous occupation by a prosperous elite from the thirteenth to the sixteenth century. The ceramic assemblages collected here in 1998 and 2004 had a higher proportion of early Chinese tradewares than the palace sites of other Bugis kingdoms. The hill is also remarkable for the number of Cizhu sherds recovered from surface collections; almost without exception, these sherds are found only on major palace sites (Bulbeck and Caldwell 2008:9).

No other archaelogical site in peninsular South Sulawesi has yielded such early evidence of political centralization. The location of the site corresponds with the tradition recorded in Bugis genealogies that the royal families of Cina and Luwuq are descended from a single founding ancestor, the to manurung Simpurusia, who appeared at Lompoq, a hill on the outskirts of Sengkang (Bulbeck and Caldwell 2000:104). The CVG states that:

When he knew that his wife had arisen in Luwuq, Simpurusia went down to Luwuq. His wife came, she who was made Arung [ruler] at Luwuq. They had two children, one called Batari Toja and one called Wé Jangkeqwanua. Batari Toja was made Datu of Luwuq. Wé Jangkeqwanua married her cousin, the child of Linruttalaga of Uriling, [that is] the sister of Da La Ako. He was called La Tupusoloq. Their child was La Malalaé. La Malalaé married his cousin, the child of Batari Toja, who is called Wé Matengngaémpong, and their child was La Sengngeng.

CALDWELL 1988:92

17 In the La Galigo, the kingdom of Cina has two palace sites: Cina ri Aja and Cina ri Lauq (West and East Cina) (Kern 1939:241). East Cina is generally believed to have been located at Sumpang Alleq, approximately six kilometres south of Sarapao. Wé Cudaiq is heir to Cina ri Aja, where the palace La Tanété is situated; her older sister Wé Tenriésaq rules in Cina ri Lauq (personal communication with Sirtjo Koolhof, 14-03-2016). 
In this succinct account, the CVG specifies that the ruling families of both Luwuq and Cina originate from the same ancestor, Simpurusia. He had two daughters, Batari Toja and We Jangkeqwanua; the first became the ruler of Luwuq and the second became the ruler of Cina. This same founding myth is found, with slight variations, in the royal genealogies of Luwuq (Caldwell 1999), implying that the ruling elites of Luwuq and Cina once comprised a single kinship group, with two branches of equal status.

Other sources also attest to the close familial relations between the ruling families of Cina and Luwuq. NGB 99:243 provides evidence that the two kingdoms maintained kinship relations well into the fifteenth century. This manuscript records the marriage of the daughter of La Pasangkadi, one of the first convincingly historical rulers, to La Paliburung of Luwuq. This union produced one child, La Usa. Wé Teppodinro and La Paliburung divorced, and La Paliburung returned to Luwuq, as did his son, La Usa. La Usa's teknonym was To Pajung, father of the Pajung (ruler of) Luwuq. In a later generation, La Térénga, the son of La Panyorongi, the ruler of Cina, married Wé Apputana of Luwuq. The closeness of these familial relationships is illustrated by the fact that La Térénga was a nephew of La Usa, and, as suggested by La Usa's teknonym, a cousin of the ruler of Luwuq.

Evidence of Cina's former importance can be gathered from the chronicles of neighbouring kingdoms through a study of local conquests, the significance of which has not previously been appreciated. The chronicles of Wajoq record how the early-sixteenth-century ruler La Tadampareq seized Sengkang, Wage, Tempe, and Tampangeng in the northwestern or upper Cenrana valley (Noorduyn 1955:178-9). These settlements are referred to in the Lontaraq sukkunaq Wajoq (The history of the Wajorese people) as tana pole ri Mancapai, the lands which come down from Majapahit (Zainal Abdin 1985:202). The Attoriolonna Simpurusia (The origin stories of the rulers of Luwuq) also states that earth from Mancapai was brought to Luwuq by the men of Wage, Tempe, and Sengkang, who met at Tampangeng (today a suburb of Sengkang), and that these settlements were called 'the lands which are kept' (Caldwell 1988:46). We believe, based on the evidence of the CVG, that these lands constituted the original heartland of Cina. This interpretation is supported by a modern-day oral tradition which says that Tampangeng was once part of Cina (Caldwell and Druce 1998:15). These four settlements were seized around 1500 by La Tadampareq, Puang ri Maqgalatung. ${ }^{18}$ This dramatic event appears to lie

18 The seizure of these settlements would have given Wajoq control of trade from the central, rice-growing regions down the Cenrana River to the east coast. 
behind the story of the change of Cina's name to Pammana at the request of the late sixteenth-century ruler La Sangaji Pammana. This story is likely to be a metaphor for the seizure of Cina's ancestral lands. ${ }^{19}$

Similarly, the Chronicle of Bone provides evidence for the expansion of Bone on Cina's lands north of Watampone. It describes how Mampu becomes a vassal of Bone under the early sixteenth-century ruler La Tenrisukki:

Also when he [La Tenrisukki] was ruling in Boné the people of Mampu and the people of Boné quarreled. War broke out between them and they raised the war cry against each other so that they clashed south of Itterung. The people of Mampu were repulsed and made to go back to their territory. Then ArumMampu went out and made obeisance offering a thousand-fold ransom. 'You may do anything, ArumPoné, if only you do not send away [from me] my child and my wife.'

ArumPoné said 'I only send you home, ArumMampu, you establish yourself as a vassal of Boné, you are not unimportant in Boné, you do not lack pure gold, long cloths, long possessions for you to hand on to your descendants.'

After that the ArumMampu was sworn [to loyalty]. After ArumMampu and his retinue were sworn [to loyalty], ArumMampu returned to his territory.

MACKNIGHT and MUHKLIS, unpublished

Although the chronicle is silent as to the reason for the quarrel, geography offers us clues. Mampu lies directly east of Amali and was very likely a constituent chiefdom of Cina. After absorbing Mampu, Bone could attack the fortified settlement on the mouth of the Cenrana river that had been established by Déwaraja, ruler of Luwuq (c. 1490-c. 1520), in apparent response to the seizure by Wajoq of Cina's lands around Sengkang. The chronicles of Bone and Wajoq record how this stronghold was captured by Bone from Luwuq after a series of attacks by Bone during the mid-sixteenth century. ${ }^{20}$ Thereafter, Bone had control of the mouth of the Cenrana river.

Cina's expansion of agriculture on to forested lands to its south and west would have required a reliable supply of iron implements, including the ubiq-

\footnotetext{
19 Pammana's political relations varied over time. Lying on the border of Wajoq, it was at times affiliated with Wajoq and at other times with Bone (L. Andaya 1981:42-3).

20 The Chronicle of Gowa also records a conquest of Cenrana by Gowa's mid-sixteenthcentury ruler Tunipalangga (Cummings 2007:33).
} 
uitous parang, a long slashing knife with a weighted tip that could double as a weapon. Bulbeck and Caldwell argue that the source of this iron was Luwuq. They hypothesize that by 1300 Bugis migrants from the central lakes region, led by members of Cina's ruling family, had established a settlement at Malangke on the northern coast of the Gulf of Bone. The settlement traded with the Lemolang-speaking polity of Baebunta that lay at the foot of the Rongkong valley, from which the iron ore was sourced. This settlement evolved into the Bugis kingdom of Luwuq (Bulbeck and Caldwell 2000).

After Cina's demise in the sixteenth century, Luwuq seems to have gone into decline and come under Gowa's influence. Its palace site at Malangke was abandoned abruptly in the first decades of the seventeenth century. ${ }^{21} \mathrm{~A}$ rump polity moved to Palopo, where it could trade with the Toraja to the north and west, but Luwuq was by now a shadow of its former self. When James Brooke visited Palopo, in 1840 , he was singularly unimpressed:

Luwu is the oldest Bugis state and the most decayed [...] Palopo is a miserable town, consisting of about 300 houses, scattered and dilapidated [...]. It is difficult to believe that Luwu could ever have been a powerful state, except in a very low stage of native civilization [...]. The entire country is wretchedly poor.

MUNDY 1848:154-5

Nevertheless, a memory of Luwuq's former greatness lingered on. Sir Thomas Stamford Raffles noted: 'In Luwu, particularly, the sovereign possesses a title with more pomp and state attached to it than any other on the island but with scarcely a shadow of authority' (Raffles 1817: Appendix F:cxi) Luwuq continued to exist as a kingdom until the advent of Dutch colonialism in the early twentieth century. To this day, Luwuq's ruling family is considered to represent the most ancient ruling lineage in South Sulawesi. We would argue that this prestige not only reflects Luwuq's formidable military might and economic prosperity in the fifteenth and sixteenth centuries, but also contains an echo of Cina's prestige as the earliest important Bugis kingdom.

21 Based on the evidence of looted burial grounds, the estimated population of Malangke dropped from 14,500 in the sixteenth century to 900 in the seventeenth century (Bulbeck and Caldwell 2000: Table 2-9). 


\section{Historical Anomalies in the History of South Sulawesi}

Our new understanding of the antiquity, size, and importance of Cina has wideranging implications for the early history of South Sulawesi. It enhances our understanding of the political landscape in which emerged later kingdoms such as Bone, Soppeng, and Wajoq. It allows us to understand details in Bugis historical sources, the importance of which was previously not recognized. It also enables us to explain various anomalies in the conventional depictions of South Sulawesi's past. In this next section, we will examine the implications of our findings through the examination of the histories of three neighbouring kingdoms.

\section{Bone}

The Chronicle of Bone is representative of other Bugis chronicles in that it describes the formation of Bone as the absorption of pre-existing agricultural communities (wanua) without reference to previous political affiliations. It describes how Bone's third ruler, La Saliu, also known as Kerrampélua, expanded his kingdom in the mid- to late fifteenth century from a cluster of settlements around Watampone to lands north of the Pacing River and south of the Pattiro River, through a mixture of conquest and alliance (Figure 2). The chronicle opens with the telling statement that 'There were kings, so the story goes, back in [the age of] Galigo, but then no longer was there anyone called king'. It describes a period of chaos during which 'The people just ate each other like fish do. They were selling each other all the time [as slaves]. There was no longer customary order, let alone what might be called law' (Macknight and Muhklis, unpublished).

Despite extensive archaeological research, no evidence has been found for either an earlier age of trade-based kingdoms or a subsequent period of political disorder. The metaphor of people eating each other like fish is derived from Sanskrit traditions, presumably via Java (Macknight and Mukhlis, unpublished), and could be interpreted as a trope associated with the beginning of things. Alternatively, it might be interpreted as a memory of the warfare that seems to have taken place during the period of Bone's gradual expansion into what appear to have been Cina's lands. The chronicle's reference to the 'kings of Galigo' could of course be explained as a general reference to the La Galigo stories. However, the chronicler was writing little more than a century after Cina's demise, thus it seems possible that this is a direct reference to Cina.

This latter interpretation is supported by the Chronicle of Bone's account of the reign of La Saliu, who ruled Bone for 72 years as child and man in the mid- to late fifteenth century. After describing his practice of cursing the enemy before 


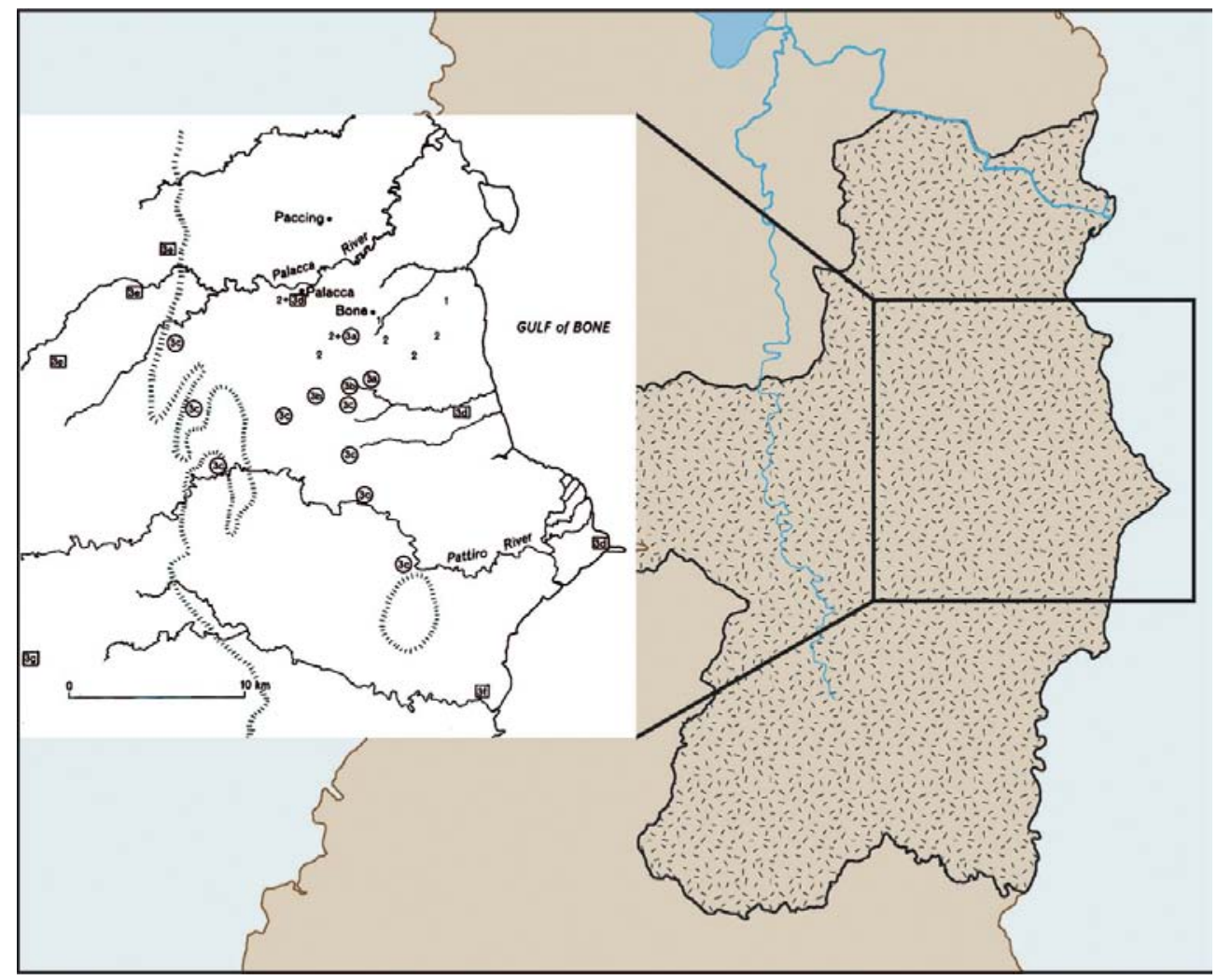

FIGURE 2 Expansion of Bone under La Saliu AFTER MACKNIGHT 1983:104

an attack, the chronicle pointedly states: 'the earlier kings who went back to Galigo had already organized [the conduct of] negotiations as well as of giving orders'. This remark suggests that prior to the development of Bone under La Saliu there was an established system of governance and diplomacy among the Bugis. This interpretation suggests that Bone was not expanding into a political vacuum, but was wresting new lands from the older kingdom of Cina.

The Chronicle of Bone's account of the fourth ruler, Wé Benrigauq (also known as Makkalempié), who ruled for four years during the early sixteenth century, may also contain oblique references to Cina. Wé Benrigauq is stated to have bought 'the hill of Cina' for 90 buffalo bulls and ordered people to settle on it and to lay out gardens. Abdicating in favour of her son La Tenrisukki, she went to live with her younger son La Tenrigorreq in Cina, where she disappeared in a fire. Wé Benrigauq was posthumously known as Mallaqjangngné ri Cina, 'she who disappeared in Cina'. 


\section{The Lateness of the Unification of Soppeng}

A striking feature of South Sulawesi's early history is the relative lateness of Soppeng's coalescence into a single kingdom. Archaeological evidence shows that the Walanae valley in which Soppeng is located was occupied by at least the first millennium BCE (Bulbeck 2008:200). ${ }^{22}$ Soppeng's written records extend back to the advent of writing around $1400 \mathrm{CE}$ and contain the names of four legendary rulers who are believed to have ruled in the fourteenth century. These written records suggest an early relationship with Suppaq, a deep-water port on the northwest coast of the peninsula. These records provide significant detail on Soppeng's early fifteenth-century ruler, Wé Tékkéwanua, who is claimed to have ruled both at Soppeng and at Suppaq. She is described in both written and oral traditions as a powerful leader who relocated hill populations in order to expand agriculture around Lake Tempe. Her reign is recalled as a time of agricultural expansion, political order, and economic prosperity. After Wé Tékkéwanua, Soppeng's royal genealogy provides a list of nine rulers, up to and including Béoé, who converted to Islam in 1609. According to tradition, however, West Soppeng (Soppéng ri Aja) was united with East Soppeng (Soppéng ri Lauq) to form a single kingdom only in the mid-sixteenth century by La Mataesso (the Sun King), who drove his cousin La Makkaroda out of East Soppeng (Abdurrazak 1967:10) Figure 3 shows West Soppeng around 1500, prior to the formation of the kingdom of Soppeng. What is striking is the smallness of the polity. Given the rich agricultural potential of the region, and the evidence elsewhere on the peninsula of centralized rulership dating back to at least the fourteenth century, why did it take so long for a unified kingdom to appear in the Walanae valley?

The reason for this historical anomaly appears to be that before the midsixteenth century West Soppeng was simply a tributary chiefdom of Cina. Tributary chiefdoms were the components that made up what historians call kingdoms and archaeologists call complex chiefdoms. The ruler of a kingdom was in effect a primus inter pares in that he or she was the most important of a region's chiefs. Prior to the seventeenth century it was generally with the families of these tributary chiefdoms that the ruling family of each kingdom married. The tributary and domain list of Soppeng, composed in the late seventeenth century (Druce 2014), names Soppeng's tributaries as Lamuru, Marioriawo, Goagoa, Pattojo, Ujumpulu, Lompengeng, Baringeng, Tanah Tengah,

\footnotetext{
22 Soppeng is famous for the large number of megaliths found around its palace site at Watansoppeng. These include menhir (upright stones), batu lesung (ritual pounding mortars), and dakon (a board game with nine rows of nine holes, played at death ceremonies); see Hasanuddin 2015.
} 


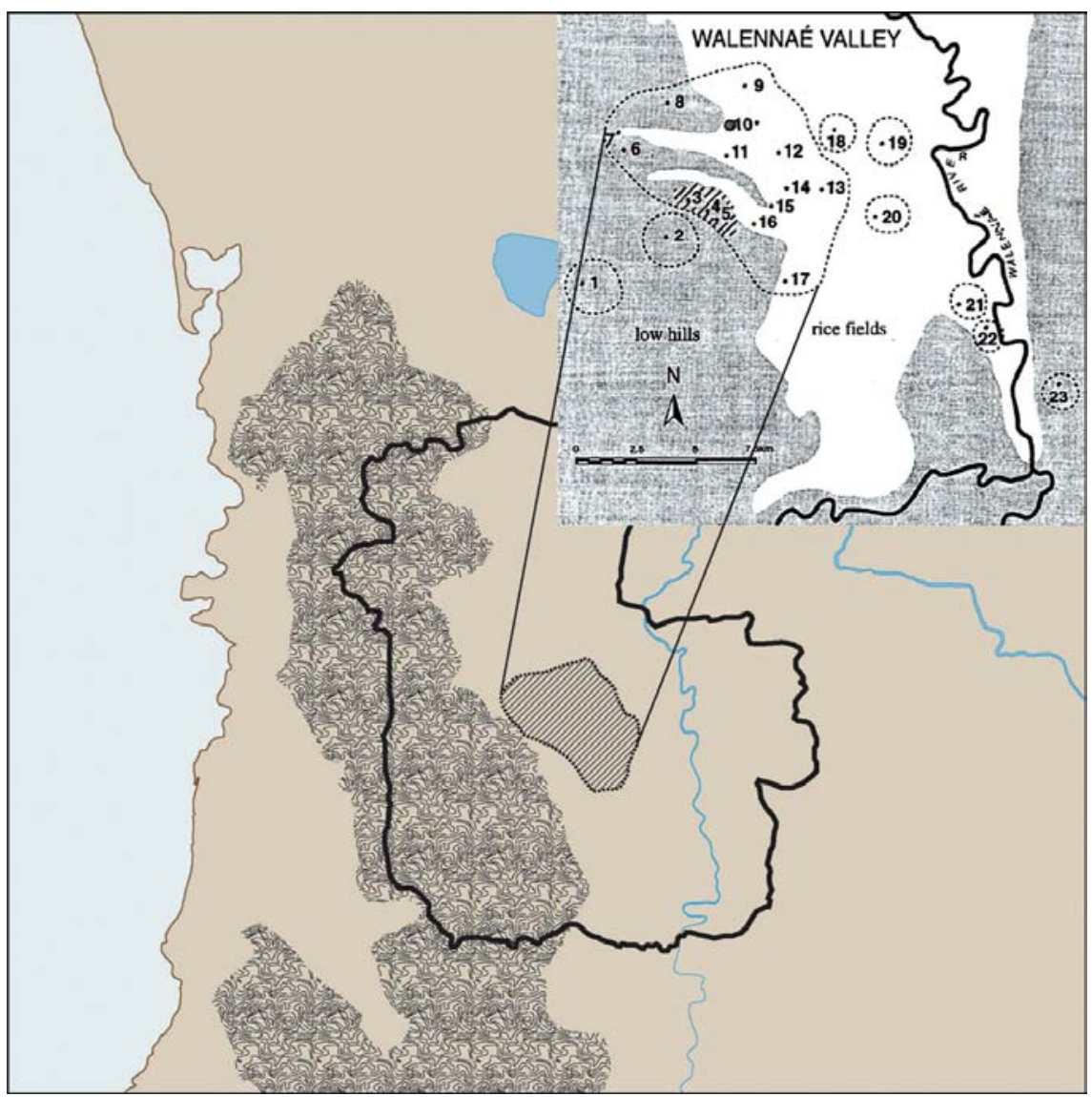

FIGURE 3 Chiefdom of West Soppeng before c. $155^{\circ}$

AFTER CALDWELL 1995: FIGURE 2

Appanang, Belo, Ganra, Bekkeq, Leworong, Marioriawaq, and Citta (Caldwell 1988:134). Before the mid-sixteenth century there is only one marriage recorded between West Soppeng and these chiefdoms; this marriage took place with a member of the ruling elite of Baringeng, a palace site founded by Cina in the fifteenth century (Caldwell 1988:167). The CVG, however, records that the ruling family of Cina concluded marriages at five of these chiefdoms: Lompengeng, Pattojo, Ujumpulu, Ganra, and Marioriawo. The rulers of Cina also concluded three marriages with the chiefdom of West Soppeng; in each instance a woman from Soppeng was married to a man from Cina. It seems likely that before the mid-sixteenth century most of the Walanae valley was under Cina's sway, and that the tradition that Soppeng was established as an independent kingdom by West Soppeng's twelfth ruler, La Mataesso, is correct. 
Our hypothesis that Cina was the dominant power in the Walanae valley before Soppeng's unification is supported, albeit obliquely, by the origin story of Soppeng.

This is the writing that tells of the land of Soppeng, those whose ancestry could be traced to the age of Galigo were no more. Gattarang and Sewo were left and the people came down and settled at Soppeng. The people of Sewo were called the people of West Soppeng and the people of Gattarang were called the people of East Soppeng. There were sixty headmanships in East Soppeng and West Soppeng and the body of the people of Soppeng was divided in two.

CALDWELL 1988:109

As in the Chronicle of Bone, the name Cina does not occur, but an earlier political elite is referred to by the term 'Galigo'. The origin story of Soppeng describes how

for seven generations [lapiq, layers] the people of Soppeng were without lords. Those whose ancestry could be traced to the age of Galigo were no more, and the sixty headmen alone ruled the land. Then our lord appeared at Sekkanyili.

This heaven-descended being was proclaimed as the first ruler of the kingdom of Soppeng, comprising West Soppeng, East Soppeng (a southern polity centred in Gattarang), and what were evidently Cina's former tributary chiefdoms in the Walanae valley. As with Bone, it seems clear that Soppeng did not emerge in a political vacuum.

\section{Luwuq as the Cradle of Bugis Civilization}

Another major puzzle in the historiography of South Sulawesi is why the kingdom of Luwuq is traditionally held to be the cradle of Bugis civilization. This kingdom lay on the northern shore of the Gulf of Bone, a region populated by non-Bugis speakers. ${ }^{23}$ Its palace site was established around 1300 at Malangke, northeast of Palopo, and was abandoned in the early seventeenth century. It is estimated that even at its sixteenth-century zenith there were never more

23 The kingdom seems to have referred to itself as Wareq. The modern-day town of Palopo is sometimes called Waraq by the people of Malangke; the distinction between Wareq (Malangke) and Waraq (Palopo) was emphasized to Caldwell when he visited Malangke in 1995 . 
than 15,000 people living at Malangke; moreover, not all of these would have been Bugis. Poorly suited for agriculture, Malangke's staple was sago and its economy was based on iron-smelting and forging (Bulbeck, Bowdery, and Field 2007). Quite why a cluster of industrial settlements in a marginal, non-Bugis area, whose population subsisted on the pith of a swamp palm, should give rise to a civilization based on irrigated wet-rice agriculture on the southern peninsula has never been addressed.

In his Descriptive dictionary of the Indian islands and adjacent countries, the British administrator John Crawfurd suggested that the Bugis homeland was 'very likely' to be in the region of the central lakes (Crawfurd 1856:74). This suggestion was ignored for almost a century and a half, during which period Luwuq was repeatedly identified as the cradle of Bugis civilization (Van Braam Morris 1889; L. Andaya 1981; Pelras 1996). Crawfurd's suggestion was based on the fact that the central lakes region constitutes the most fertile and productive land on the peninsula. Evidence from the oxis project that complex society in the central lakes region predates by at least a century the Bugis settlement at Malangke strongly supports Crawfurd's hypothesis. It would thus appear that Luwuq was an outpost rather than the homeland of the Bugis.

Luwuq's political and military involvement on the peninsula of South Sulawesi prior to 1600 is as puzzling as the claim for its antiquity. Writing in 1759, a Dutch governor of Makassar reported the tradition that, in addition to the Gulf of Bone, Luwuq held sway over all of Wajoq, much of Bone, and the entire coastline from Bone to modern-day Jeneponto (Blok 1817:3-4). This tradition is supported by other sources. A mid-fifteenth-century peace treaty between Bone and Luwuq sets out Bone's status as a child of Luwuq (LKL:375); a chronicle of Wajoq records that Luwuq's rulers collected taxes in Wajoq (Zainal Abidin 1985:64); and the early sixteenth century Luwurese ruler Déwaraja based himself at a fortified settlement near the mouth of the Cenrana river (Zainal Abidin 1983:210). With Wajoq's assistance, Luwuq launched three attacks on the emerging kingdom of Sidenreng during the early sixteenth century. Not long after sacking and burning Sidenreng's palace site, Luwuq attacked Bone, this time with disastrous consequences. Luwuq's army was slaughtered at Attasalo and its ruler, Déwaraja, was allowed to escape back to Luwuq with just 20 of his men.

Considering that Luwuq's iron-based political economy was radically different from the economies of the kingdoms of the southern peninsula, its historical preoccupation with suppressing emerging agricultural polities in Bone and east of the central lakes requires explanation. Logically, Luwuq should have been a natural trading partner for these kingdoms. Instead, it was a veritable policeman, raising armies of hill tribes and transporting them by boat along 
the coast in order to exert its authority. The explanation for Luwuq's anomalous behaviour appears to lie in its close relationship with Cina. If we accept that the ruling families of Luwuq and Cina originated from a single kinship group, and that a relationship between the two kingdoms was maintained through marriages and shared economic interests, Luwuq's suppression of upstart kingdoms on the borders of Cina makes good sense. Evidence of a close historical relationship between the two kingdoms persists even to this day. On the modern ruling council (hadat) of Luwuq, three of the twelve seats represent the headmen (matoa) of Wage, Tempe, and Tampangeng. ${ }^{24}$ These are the lands that, according to the eighteenth-century chronicles of Wajoq, were Luwuq's ancestral territories, and the heartlands of Cina in the CVG. Seen in this light, Luwuq's strategic interest in Cina's affairs seems perfectly understandable.

\section{A New Paradigm for Early Bugis History}

If we accept that Cina was a large and influential polity that dominated the rice-growing lowlands south of the Cenrana River and around Lake Tempe, and that Luwuq rose to pre-eminence through a symbiotic relationship with Cina, it becomes possible to construct the outlines of an integrated history of the peninsula. ${ }^{25}$ We believe that this new understanding completes the paradigm shift begun by the oxis project and continued after 2000 in the work of individual scholars. At the very centre of this new understanding is the idea of Cina as an early and influential polity, hidden behind the foundation of later Bugis kingdoms. ${ }^{26}$

Cina appears to have developed as a complex chiefdom from alliances among a group of small polities located in the upper Cenrana valley. The chronicles of Wajoq name Sengkang as one of the four ancestral or ancient lands of Luwuq. As previously argued, we believe these comprised the heartland of Cina. The low hill on which the town of Sengkang sits, lies at a natural point of advantage for the central lakes region and the rice-growing plains to the south. Its name appears to derive from (Bugis) si+engka+ng meaning 'com-

\footnotetext{
24 Personal communication to Caldwell by Andi Maradang Makulau, Datu Luwu XL, Palopo, September 2014 .

25 Little is yet known of the Toraja uplands and Mandar, but these regions are peripheral to the main story.

26 Pelras (2010), which the authors read after the completion of this article, makes similar arguments, but provides no evidence or sources. His interpretation is presumably based on the La Galigo.
} 
ing together' and may refer to the point where the Walenae River joins the Bila River as it exits Lake Tempe to form the Cenrana river. Whoever commanded this strategic point controlled the important trade route to the sea, as well as the surrounding agricultural lands. The geographic advantages of the molasse ridge on which Sengkang sits contextualize the statement in the CVG that Simpurusia, the founder of Luwuq and Cina, descended at Lompoq, a hill on the northern outskirts of Sengkang, and that his wife, Pattiaqjala, arose from the water foam at Tampangeng in south Sengkang. The widespread tradition that Cina's main palace was at Sarapao in We Cudai village, on the same ridge, south of Sengkang, is supported by archaeological evidence from Allangkanangnge. Ceramic and radiocarbon dating show that a palace site was established here in the thirteenth century and was continuously occupied until the mid-seventeenth century. While isolated today, marine shellfish excavated at Allangkanangnge have been dated to the thirteenth to fifteenth centuries, suggesting that it may once have been closer to the coast (Bulbeck et al. forthcoming). ${ }^{27}$

At its zenith, Cina appears to have comprised a coalition of internally selfgoverning polities scattered across the landscape of the central peninsula. According to the La Galigo, Cina's influence extended over a wide area including the settlements of Soppeng ri Aja, Soppeng ri Lauq, Lempanglempang, Saqbamparu, Paccing, Tempe, Wage, Teamusuq, Limpomajang, Lampoko, Lompengeng, Canru, Maruq, Ganra, Saburo, Balangnipa, Laju, Pationgi, Bombangcina, Salotungo, Buludua, and Lamuru (Kern 1939:287, 317-8). As previously emphasized, the picture provided by the La Galigo should be treated with caution. ${ }^{28}$ However, it is noteworthy that most of these toponyms can be identified on modern-day maps, spread over a wide area of the central peninsula from the central lakes in the north to Sinjai in the south (Figure 4).

27 It is possible that the Cenrana valley has risen relative to sea level in recent centuries because of tectonic uplift; see Gremmen 1990, and Caldwell and Lillie 2004. The most recent sea level maxima detected off the southwest peninsula were measured 4500 and 1600 years ago, when the sea level was respectively 5 and 2.5 metres higher than present (Whitten 1987:18-9). In the upper valley, marshy ground has been drained for agriculture and the clearing of forest cover has contributed to sedimentation of lower-lying land.

In the La Galigo the terms to Cina (the people of Cina) and to ugiq (the Bugis) are used interchangeably. Timorese oral history records an early settlement site, Tutuala, at the easternmost tip of Timor Leste called Cina Ratu (personal communication with Sue O'Connor, 02-02-2016). It seems possible that 'Cina' was a general term for visitors from South Sulawesi, just as 'Bugis' is sometimes used today. 


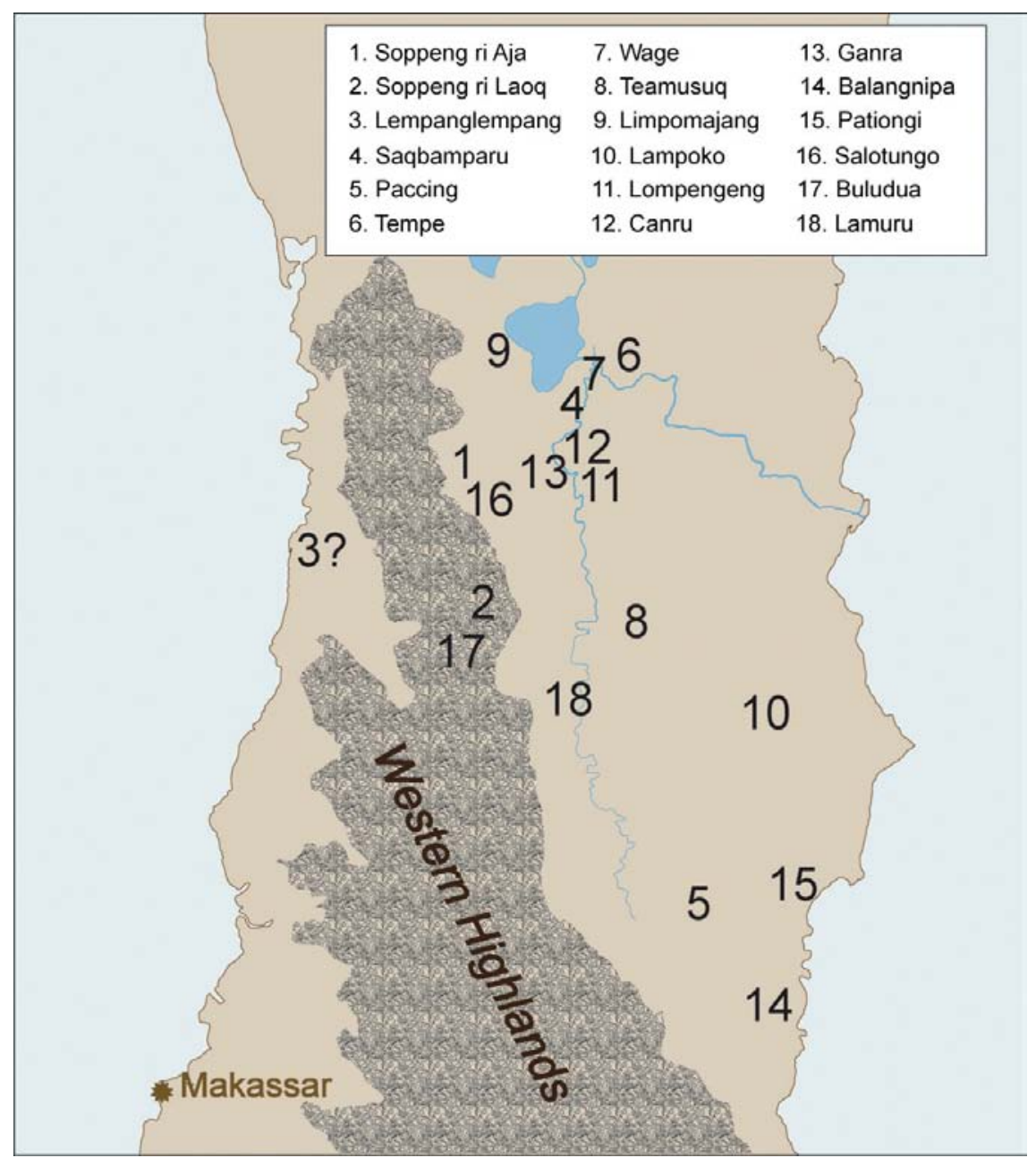

FIGURE 4 Constituent chiefdoms of Cina according to the La Galigo KERN 1939:287, 317-8

If one looks carefully, there are scattered textual references to Cina in several Bugis historical works. These sources rarely mention the name Cina, but instead use the name Galigo, or simply refer to what we have argued were parts of Cina by local toponyms. The Chronicle of Bone reveals the way that Bone's third ruler, La Saliu, used pre-existing political and diplomatic systems to create a new kingdom. The chronicle emphasizes that these principles were not his creations; indeed, the chronicler states that La Saliu was 'not said to be especially clever', describing him instead as brave, skilful, and vigilant. The chronicle states that La Saliu used established principles and practices of statecraft as 
well as warfare to consolidate his expanding kingdom. It records that: 'The earlier kings who went back to Galigo had already organized [the conduct of] negotiations as well as of giving orders'. This seems to imply both a hierarchical ordering of chiefdoms and a set of diplomatic principles by which this order was maintained. The rule that messengers were not to be harmed, whatever the contents of their communications, appears to have been established by the fifteenth century. The Chronicle of Bone records that when the ruler of Katumpiq killed a messenger sent by Bone's third ruler, La Saliu, Bone declared war on Katumpiq (Macknight and Muklis, unpublished). Another example may be the practice of summoning the tributary chiefdoms and their warriors using bilabila, a strip of palm leaf with a number of knots corresponding to the number of days in which a tributary chief and his warriors were expected to report to their overlord (L. Andaya 1981:55). Although, as we have argued, Cina was absorbed in the sixteenth century by agricultural chiefdoms to its north, south, and west, it would seem that by this time basic principles of Bugis political life had already been established.

Luwuq's political importance in early South Sulawesi appears to have been based in part on its special relationship with Cina, as well as on its ability to command the hill tribes in surrounding upland regions and the coastal Bajo. ${ }^{29}$ As we have documented, Cina and Luwuq were connected by shared royal ancestry and this connection was maintained by marriage, into at least the fifteenth century. The closeness of Cina and Luwuq's historical relationship is personified in the La Galigo by the marriage of Sawerigading, prince of Luwuq, to his cousin Wé Cudaiq, princess of Cina. There is evidence of economic exchange between Cina and Luwuq in the form of distinctive, reddish, 'soft' pottery sherds found at Allangkanangnge and in Luwu. ${ }^{30}$ Given the abundance of iron ore in the highlands of Luwu (Caldwell 2014) and the region's unsuitability for the growing of rice, it seems logical that Luwuq provided Cina with iron tools and weapons, and that Cina provided Luwuq with foodstuffs, cloths, and ceramic wares. ${ }^{31}$ Luwuq may also have sold iron to Majapahit: there

29 Personal communication with Andi Anton, 1995. The people of Rongkong, a mountain valley north of Baebunta, claim to have been renowned for their martial prowess, as well as their fierce loyalty to the Datu Luwuq (Caldwell 2014:60).

Budianto Hakim of the Balai Arkeologi Makassar, identified a handful of soft-pottery sherds in the Allangkanangnge assemblage as being the same, or closely similar, to those excavated in Luwuq in 1997 by the oxis project (Bulbeck et al. forthcoming).

31 Large quantities of Chinese and Southeast Asian ceramics were imported to South Sulawesi after c. 1200. Several woodblock-printed Guajarati textiles from South Sulawesi have been radiocarbon-dated to the fourteenth and fifteenth centuries (Guy 1998). 
are references to Majapahit in Bugis sources, as well as settlements of that name in Wajoq and Bone and in southeast Sulawesi. ${ }^{32}$ There is also a type of Javanese kris with a pattern-welded inlay called pamor Luwuq (Solyom and Solyom 1978:18; Bronson 1987:13). There are references to Mancapai in Bugis written traditions and a place of this name on the southeastern peninsula of Sulawesi, as well as coastal settlements called Garisi, Tuban, and Suruboyo in South Sulawesi. In the Desawarnana, written in Java in 1365 , Luwuq is grouped with Bantayan (Bantaeng) and an unidentified polity called Uda, 'these being the three foremost places in the island' (Robson 1995:34). In the light of our new understanding of Cina it seems likely that Uḍa, which Pigeaud (1962:17) could not identify, is the kingdom of Cina.

Cina and Luwuq's joint economic success appears in the long run to have stimulated the rise of challenger polities. These challenges may have been facilitated in part by the spread of iron technology, as well as by political weaknesses in Cina upon which La Saliu, La Tadamparaq, and La Mataesso capitalized. The core areas of Bone, Wajoq, and Soppeng all lie on the margins of what we believe to have been the kingdom of Cina. It appears that these newer kingdoms arose in the context of a pre-existing complex society with a developed political culture. The rise of these new kingdoms constituted local challenges to the power of Cina and Luwuq and account for Luwuq's aggressive behaviour towards upstart agricultural polities on the borders of Cina. These challenges eventually resulted in the dismemberment of Cina and its absorption into these new kingdoms.

Based on the evidence presented in this article we believe that Cina and Luwuq were ruled initially by a single corporate cognatic descent group that later bifurcated into two different kingdoms. At least until the mid-fifteenth century one could consider Cina and Luwuq as complementary elements of a single political complex. Both kingdoms claimed the same founding ancestor, Simpurusia, as the progenitor of their royal families. The settlements of Tempe, Wage, Tampangeng, and Sengkang, which are referred to in the chronicles of Wajoq as the ancestral lands of Luwuq, appear on the evidence of the CVG to have constituted the heartlands of Cina. It is possible that the chronicles of Wajoq may have attributed these lands to Luwuq in order to avoid referring to Cina, or it may simply have been that the two kingdoms were synonymous in the minds of the chroniclers. ${ }^{33}$

\footnotetext{
32 Reflecting on the reference to Luwuq in the Desawarnana (Nagarakertagama), L. Andaya (1981:18) suggests that Luwuq 'would have found a ready market for its iron in Majapahit'.

33 The origin of these lands is accounted for in the Attoriolonna Simpurusia (Story of the founding family of Luwuq and Cina) as forming part of the dowry of Wé Tappaqcinna, a
} 
At the beginning of this article we drew attention to the paucity of references to Cina in Bugis historical sources, despite the kingdom's important role in the La Galigo stories. We believe we have come some way towards resolving this discrepancy, in that our new interpretation is significantly closer to the portrayal of Cina in the literary sources. Some problems remain, such as the apparent emphasis in the La Galigo stories on trade as the basis of Cina's economy. However, trade was important in the early Bugis kingdoms, as is attested by the thousands of sherds of Chinese and mainland Southeast Asian ceramics scattered across the historical landscape of South Sulawesi. Bulbeck and Caldwell (2000) have argued that trade was the stimulus that gave rise to the agricultural kingdoms via a complex multiplier effect (Renfrew 1972: Chapter 3) and that trade and agriculture were complementary aspects of South Sulawesi's political economy. Similarly, Cina and Luwuq, with their radically different economic bases, are interpreted here as symbiotic branches of a single economic system.

It now seems possible to establish agreement among historians as to the chronology of early South Sulawesi. It is no longer necessary to create an 'Age of Galigo' in the period 1000-1300. There is no archaeological evidence for the existence of kingdoms or complex chiefdoms before the thirteenth century, nor is there evidence of a general political breakdown or 'multifaceted upheaval' around the fourteenth century (Pelras 1996:107). Instead, both archaeological and historical sources indicate a growing economy as well as a lively struggle for power across the peninsula in this century. Nevertheless, Christian Pelras's strong emphasis on the importance of Cina in the development of Bugis complex society now appears essentially correct.

\section{References}

Abdurrazak, Daeng Patunru (1964). Sedjarah Wadjo. Udjung Pandang: Jajasan Kebudajaan Sulawesi Selatan dan Tenggara.

Abdurrazak, Daeng Patunru (1967). 'Sedjarah-ringkas kerajaan Soppeng', Bingkisan 1:512.

Abdurrazak, Daeng Patunru (1968). Sedjarah Bone. Makassar: Yajasan Kebudayaan Sulawesi Selatan dan Tenggara.

Andaya, B.W. (1993). To live as brothers: Southeast Sumatra in the seventeenth and eighteenth centuries. Honolulu: University of Hawaii Press.

princess of Majapahit (Caldwell 1988:46). This suggests that they were among the earliest settlements of Cina. 
Andaya, L.Y. (1981). The heritage of Arung Palakka: A history of South Sulawesi (Celebes) in the seventeenth century. The Hague: Nijhoff.

Blok, R. (1817). History of the island of Celebes. Calcutta: Calcutta Gazette Press.

Bougas, Wayne (1998). 'Bantayan: An early Makassarese kingdom 1200-1600 AD', Archipel 55:83-123.

Braam Morris, D.F. van (1889). 'Het landschap Loewoe', Tijdschrift van het Bataviaasch Genootschap van Kunsten en Wetenschappen 32:497-530.

Bronson, B. (1987). 'Terrestrial and meteoritic nickel in the Indonesian kris', Journal of the Historical Metallurgical Society 21-1:8-15.

Bulbeck, David (200o). 'Economy, military and ideology in pre-Islamic Luwu, South Sulawesi, Indonesia', Australian Historical Archaeology 18:3-16.

Bulbeck, David (2008). 'An archaeological perspective on the diversification of the languages of the South Sulawesi stock', in: Truman Simanjuntak (ed.), Austronesian in Sulawesi, pp. 185-212. Yogyakarta: Galang Press.

Bulbeck, F.D., D. Bowdery, and J. Field (2007). 'The palace centre of Sago City: Utti Batue site, Luwu, Sulawesi, Indonesia', in: Malcolm Lillie and Stephen Ellis (eds), Wetland archaeology and environments: Regional issues, global perspectives, pp. 11941. Oxford: Oxbow Books.

Bulbeck, David and Ian Caldwell (2000). Land of iron: The historical archaeology of Luwu and the Cenrana valley. Results of the Origin of Complex Society in South Sulawesi Project (oxIs). Hull: Centre for South-East Asian Studies, University of Hull.

Bulbeck, David and Ian Caldwell (2008). 'Oryza sativa and the origins of kingdoms in South Sulawesi, Indonesia: Evidence from rice phytoliths', Indonesia and the Malay World 36:1-20.

Bulbeck, David, Ian Caldwell, Steven Druce, Budianto Hakim, Stuart Hawkins and Campbell Macknight (forthcoming). 'Survey and excavations at Allangkanangnge ri La Tanete, South Sulawesi'.

Caldwell, Ian (1988). South Sulawesi A.D.1300-160o: Ten Bugis texts. [PhD thesis, Australian National University, Canberra.]

Caldwell, Ian (1995). 'Power, state and society among the pre-Islamic Bugis', Bijdragen tot de Taal-, Land- en Volkenkunde 151:394-421.

Caldwell, Ian (1999). 'The chronology of the king list of Luwuq to A.D.1611', in: Kathryn Robinson and Mukhlis Paeni (eds), Living through histories: Culture, history and social life in South Sulawesi, pp. 29-42. Canberra: Research School of Pacific and Asian Studies, Australian National University.

Caldwell, Ian (2014). 'Through the highlands of South Sulawesi', Review of Indonesian and Malaysian Affairs 48-2:55-75.

Caldwell, Ian and Wayne Bougas (2004). 'The early history of Binamu and Bangkala, South Sulawesi', Bijdragen tot de Taal-, Land- en Volkenkunde 164:456-510.

Caldwell, I. and S. Druce (1998). 'The tributary and domain lists of Luwuq, Binamu and 
Bangkala'. http://www.oxis.org/resources-3/unpublished/caldwell-druce-1998.pdf. [Working paper.]

Caldwell, Ian and Malcolm Lillie (2004). 'Manuel Pinto's inland sea: Using palaeoenvironmental techniques to assess historical evidence from South Sulawesi', Modern Quaternary Studies of Southeast Asia 18:259-72.

Caldwell, I. and K. Wellen (2016). 'Family matters: Bugis genealogies and their contribution to Austronesian studies. In Orality, writing and history: The literature of the Bugis and Makasar of South Sulawesi', ed. Druce, S.C. International Journal of Asia Pacific Studies 12 (Supp. 1): 119-141, http://dx.doi.org/10.21315/ijaps2016.12.s1.6

Cense, A.A. (1966). 'Old Buginese and Makassarese diaries', Bijdragen tot de Taal-, Landen Volkenkunde 122:416-28.

Crawfurd, John (1856). A descriptive dictionary of the Indian islands and adjacent countries. London: Bradbury and Evans.

Cummings, William (2007). A chain of kings: The Makassarese chronicles of Gowa and Talloq. Leiden: KITLV Press.

Druce, Stephen (2009). The lands west of the lakes: A history of the Ajattappareng kingdoms of South Sulawesi, 1200 to 1600 CE. Leiden: KITLV Press.

Druce, Stephen (2014). 'Dating the tributary and domain lists of the South Sulawesi kingdoms', in: Ampuan Haji Brahim bin Ampuan Haji Tenga (ed.), Cetusan minda sarjana: Sastera dan budaya, pp. 145-56. Brunei: Dewan Bahasa dan Pustaka.

Fadillah, M. Ali and M. Irfan Mahmud (2000). Kerajaan Siang kuna: Sumber tutur, teks dan tapak arkeologi. Makassar: Balai Arkeologi Makassar dan Lembaga Penerbitan Universitas Hasanuddin.

Fadillah, M. Ali and Iwan Sumantri (eds) (200o). Kedatuan Luwu: Perspektif arkeologi, sejarah dan antropologi. Makassar: Lembaga Penerbitan Universitas Hasanuddin in cooperation with Institut Etnografi Indonesia.

Finlay, M.I. (1964). 'The Trojan War', Journal of Hellenic Studies 84:1-20.

Gremmen, W.H.E. (1990). 'Palynological investigations in the Danau Tempe depression, southwest Sulawesi (Celebes)', Modern Quaternary Research in Southeast Asia 11:12334 .

Guy, John (1998). Woven cargoes: Indian textiles in the East. London and New York: Thames and Hudson.

Hasanuddin (2015). Kebudayaan megalitik di Sulawesi Selatan dan hubungannya dengan Asia Tenggara. [PhD thesis, Universiti Sains Malaysia, Penang.]

Kallupa, Bahru, David Bulbeck, Ian Caldwell, Iwan Sumantri and Karaeng Demmanari (1989). 'Survey pusat kerajaan Soppeng 1100-1986: Final report to the Australian Myer Foundation'. Canberra. [Published privately.]

Kern, R.A. (1939). I La Galigo. Catalogus der Boegineesche, tot den I La Galigo-cyclus behoorende handschriften bewaard in het Legatum Warneranium te Leiden alsmede in andere Europeesche bibliotheken. Leiden: Legatum Warneranium and Koninklijk Instituut voor Taal-, Land- en Volkenkunde. 
Macknight, C.C. (1983). 'The rise of agriculture in South Sulawesi before 160o', Review of Indonesian and Malaysian Affairs 17:92-116.

Macknight, C.C. (2000). 'South Sulawesi chronicles and their possible models', in: Anthony Disney and Emily Booth (eds), Vasco da Gama and the linking of Europe and Asia, pp. 322-32. Oxford and New York: Oxford University Press.

Macknight, C.C. and Mukhlis Paeni (unpublished). 'The chronicle of Bone'. [Unpublished typescript.]

Mahmud, M. Irfan (2003). Kota kuno Palopo: Dimensi fisik, sosial dan kosmologi. Makassar: Masagena Press.

Mundy, R. (1848). Narrative of events in Borneo and Celebes, down to the occupation of Labuan. Vol. 1. London: John Murray.

Noorduyn, J. (1955). Een achttiende-eeuwse kroniek van Wadjo': Buginese historiography. 's-Gravenhage: Smits.

Noorduyn, J. (1961). 'Some aspects of Macassar-Buginese historiography', in: D.G.E. Hall (ed.), Historians of South-East Asia, pp. 29-36. London: Oxford University Press.

Noorduyn, J. (1965). 'Origins of South Celebes historical writing', in:Soedjatmoko, M. Ali Raden and G.J. Resink (eds), An introduction to Indonesian historiography, pp. 13755. Ithaca, NY: Cornell University Press.

Pelras, Christian (1996). The Bugis. Oxford: Blackwell.

Pigeaud, T.G.T. (1962). Java in the fourteenth century: A study in cultural history. Vol. 3: The Nāgara-kěrtāgama by Rakawi Prapañca of Majapahit, A.D.1365. The Hague: Nijhoff. Raffles, Thomas Stamford (1817). History ofJava. Vol. 2. London:John Murray.

Rahim and Ridwan Boharima (1975). Sejarah kerajaan Tallo'. Ujung Pandang: n.p.

Renfrew, C. (1972). The emergence of civilization: The Cyclades and the Agean in the third millennium B.c. London: Methuen.

Robson, S. (1995). Désawanana (Nagarakrtagama) by Mpu Prapañca. Leiden: KITLV Press.

Seymour-Smith, C. (1986). Macmillan dictionary of anthropology. London: Macmillan.

Solyom, Garrett and Bronwen Solyom (1978). The world of the Javanese keris. Honolulu, Hawaii: East-West Center.

Whitten, Anthony, Muslimin Mustafa and Gregory Henderson (1987). The ecology of Sulawesi. Yogyakarta: Gajah Mada University Press.

Wolhoff, G.J. and Abdurrahim (1969). Sedjarah Gowa. Makassar: Jajasan Kebudajaan Sulawesi Selatan dan Tenggara.

Zainal Abidin (1974). 'The I La Galigo epic cycle of South Celebes and its diffusion', (translated and adapted by C.C. Macknight), Indonesia 17:160-9.

Zainal Abidin (1983). 'The emergence of early kingdoms in Sulawesi: Preliminary remarks on governmental contracts from the thirteenth to the fifteenth century', in: Zainal Abidin, Persepsi orang Bugis, Makasartentang hukum, negara dan dunia luar, pp. 455-91. Bandung: Penerbit Alumni. 
Zainal Abidin (1985). Wajo' pada abad XV-XVI: Suatu penggalian sejarah terpendam Sulawesi Selatan dari lontara. Bandung: Penerbit Alumni.

\section{Manuscript References}

LATTM refers to Lontarak Attoreng Toriolo, Tawang Mammulangngé (1) Pemerintah daerah Tk. 1, Sulawesi Selatan, Mei 1982.

LAL refers to Lontarak Akkarungan Luwu 1985. Photocopy, owned by Muhammad Salim.

MAK refers to manuscripts (according to the old catalogue) in the Bugis and Makasar manuscript collection of the Yayasan Kebudayaan Sulawesi Selatan dan Tenggara (formerly Matthesstichting), Makassar.

NBG refers to manuscripts in the Bugis and Makasar manuscript collection of the Nederlands Bijbelgenootschap (Dutch Bible Society) (Matthes 1875,1881 ), currently held in the library of the University of Leiden. 